\title{
WeChat how to improve brand loyalty-Evidence from cosmetics industrial
}

\author{
Jinfeng $\mathrm{Li}^{1, \mathrm{a}}$, Hong Jin ${ }^{2, \mathrm{~b}}$ \\ ${ }^{1}$ school of Jiangxi Normal University, Nanchang 330022, China; \\ ${ }^{2}$ school of Jiangxi Normal University, Nanchang 330022, China. \\ a807887321@qq.com, ${ }^{\text {b3 } 342944219 @ q q . c o m ~(C o r r e s p o n d i n g ~ a u t h o r) ~}$
}

Keywords: WeChat, Cosmetics, Loyalty.

\begin{abstract}
WeChat business of Cosmetics industry rises rapidly, some phenomena appear such as "stock up goods" the rate of repeat purchase is lower and "disorderly price". This paper analyzes WeChat cosmetics status and clear up research of brand loyalty. In view of the existing problems and propose solutions. Emphasizes that merchants should attention to consumer's emotional resonance, strengthen internal management and optimize the after-sales service to enhance consumer's brand loyalty.
\end{abstract}

\section{Introduction}

Currently WeChat business is a rise of the internet marketing mode, and most WeChat businesses face a "FMCG" challenge, cosmetics is not an exception. Rate of product repeat purchase is low, and the consumer always has reservations about the product, not daring to trust. Based on the existing research of WeChat business and brand loyalty in the cosmetics, for example, using the method of literature analysis, expert interview and merchants to visit to find out the meaning of brand loyalty, measure, factors, and accordingly puts forward the solutions and suggestions to solve the problem.

\section{Literature review}

\subsection{WeChat business}

General view regards WeChat business as a "personal" be derived carrier place by using Web3.0 era, combines the traditional consumption matters and the Internet. There is no regional restriction, and it realizes mobility sales channel with new breakthroughs with mobile way in small individual behavior [1]. Cosmetics WeChat merchants adopt the direct sales model, agents directly to consumers at all levels. Agents were divided different levels by organization .This makes a lot of cosmetics merchant's product become "FMCG". It makes cosmetics such as a stream in the wave of WeChat business. Product want to be the "luxury" is harder. Agents are make "acquaintances" money in the circle of friends. Keep brush advertising is likely to make the original "strong relationship" into "weak relationship". It is extremely unfavorable for the promotion of the brand if agents in hurry to sell products rather than to cultivate customer loyalty.

\subsection{Brand loyalty}

Brand loyalty means consumers in the purchase process, often have a bias (involuntary reaction) behavioral response to a brand. It is a kind of behavior process and is also a kind of psychological bias behavior process. The formation of brand loyalty is not entirely dependent on the quality of the product, loyalty, brand association and spread, it is closely related to the characteristics of the consumers themselves [2]. Improving the brand loyalty is extremely important for the survival and development of an enterprise which wants to expand the market share. If WeChat business wants to have a foothold, it must know how to cultivate the consumer loyalty and obtain long-term interests. The improvement of brand loyalty for WeChat business not only can make themselves have a foothold but also can enhance the competitiveness of products in the same industry. The value of 
high brand loyalty has (1) lower marketing costs and increased profits. It's (2) easier to attract new customers and (3) improve sales channels and expand force. (4) In the face of the competition it has great flexibility. Customer awareness of the brand loyalty is that customers trust the brand; this is the value of the customer [3]. Cosmetics industry itself particularity determines that consumers are more sensitive, because WeChat business uses network platform online sales, rather than offline entity shop. It requires a great deal of trust, it is not enough to make customers to understand the product, if want to make sure dealer's profits it also need costumers have high loyalty to the brand.

\subsection{Research status of WeChat and brand loyalty}

Businesses release the product information on the platform and circle of friends, especially the merchants pay more attention to use the circle of friends to promote products. Cosmetic is one of the products. They tend to focus on their products publicity, rather than notice to the customer's feelings. Now, most of the research from WeChat public platform, study the influence of send content to traditional and how to use WeChat public platform to make WeChat marketing.

The existing research of WeChat business is that marketing model and the causes of its development. Circle of friends marketing communication interpretation [4]. The reason of WeChat development mostly is marketing matters of friends circle and the establishment of training system. A lot of training is sale product and recruitment agencies in essence [5]. As well as had some strengths, such as (1)with the smart phones development WeChat exist some potential customers.(2)WeChat marketing has timeliness.(3) As WeChat platform continuously improve, it provide some diversified development opportunities [6]. In terms of brand loyalty research that based on customer's value [7], How to promote brand loyalty based on the perspective of network brand community research [8]. Some research about brand loyalty from foreign, Brand innovation how to influence brand loyalty? [9], in the aspect of brand loyalty has (1) put customers first , (2) take the long view, (3) create compelling context, (4) make it a conversation (5) earn trust[10], and price promotions and brand loyalty [11]. Domestic existing research does not combine WeChat business and brand loyalty, not emphasize focus on the customer's emotion, make customer had emotional resonance, and rely on the brand, to strengthen the loyalty of the brand. Foreign countries pay more attention to study how to shape the brand loyalty.

\section{Cosmetics WeChat business current situation}

Cosmetics WeChat business adopts the direct sales model. In the WeChat businesses consumers in the product does not trust tentative purchase, so cosmetics can only walk to low and mid-range price. It is a common problem in WeChat business now. This makes a lot of cosmetics WeChat business products become "FMCG". Put attention on sales rather than consumer's emotion, this will cause antipathy of some friends and consumers. It can't promote sales but have a negative impact. It is extremely unfavorable for the promotion of the brand. How to introduce products and not to make consumers antipathy is one of the most pressing problems. In WeChat business, there still exists the irrationality of competition between internal agents, known as the "price" (below the unified price of each agent) phenomenon. This leads to a phenomenon that some agents unsold, also can give consumer a phenomenon that same product but price different from different agents and they add on price, brand management system is not perfect. Cosmetics WeChat business is mostly small brands even not well-known brands. "Disorder price" will cause difficult to build trust on product of customers and WeChat business agents are also can't use the transmission effect effectively. Followed by after-sales problem, WeChat business trade is on the basis of trust, nor any third party security agencies to protect consumer interests and rights.

\section{Strategies and Suggestions}

\subsection{Strategies}

In the first place, internal "disorder price" phenomenon need have a unified regulatory mechanism, because of WeChat and other platform has no regulatory mechanism, so requirement 
brand manager to self-built. First, if the agents have a foul, stop the agent qualification, and they don't have the opportunity to back again. This will produce a kind of psychological pressure to the agents, especially high level agents. They will not easily touch border. Second, limit agent "stock up", so the agent will not sell at a low price of goods. It also can have a "hunger marketing" effect on consumers.

Do well after-sales services, for some customers want to return product merchants should do sales-after service in time, concerned about the consumers. Holidays, send some compliments. When consumers buy products not satisfied should change product in time or give some compensation, to attain consumer satisfaction, even beyond the expectation of consumers. Customer satisfaction will produce good word-of-mouth advertising. If we want consumers' loyalty to the brand, make consumers satisfied with the product first. And then they will have the emotional dependency. To establish and perfect the after-sale service of WeChat business link for defective products, timely exchange or refund, and don't let your personal credit overdraft.

\subsection{Suggestions}

First, WeChat business merchants should provide good after-sales service, timely understand consumers' response to the products. The merchants should have complete feedback records.

Next, WeChat business merchants should have a lot of communication with consumers. In cosmetics WeChat business most consumers are female consumers. It means that businesses can be interactive, have a chat, and pay attention to emotional communication. In the circle of friends, put some women to focus on topics and your life state, make consumers know more about business and trust business more, so it can improve the trust of consumers about the product.

Finally, WeChat can set up a third-party evaluation, so that consumers can have a place to evaluate the product and to share with other consumers feelings after using the same brand cosmetics. Link WeChat business reputation and consumers' evaluation directly, and it helps businesses do pre-sale and after-sale service. It also monitors the WeChat business marketing, continuously regulates WeChat business marketing system, making efforts to create a good market environment.

\section{References}

[1]. Peng Yubing, The definition of WeChat business and current situation. The Fortune Times Vol. 11(2014) No.12, p. 29.

[2]. Su Liting, Chen Wenjun, Thinking about of brand loyalty. The Guide of Science \& Education. Vol. 15(2015) No.1, p. 29.

[3]. Ding Jing, Research of brand loyalty based on costumer's value. China Market Marketing. Vol. 15(2015) No.14, p. 72-77.

[4]. Liu Shu, Fan Kai, Circle of friends marketing communication interpretation. Brand Marketing. (2015) No.14, p. 30.

[5]. Xie Weilin, The reveal of cosmetics WeChat business. Sale and Management. Vol.11 (2015) No. 4, p. 66-67.

[6]. Bai Ning, Li Ruirui, SWOT analysis of WeChat business development. FINANCE \& ECONOMY..p.121-122.

[7]. Ding Jing, In terms of brand loyalty research that based on customer's value. China Market Marketing. Vol. 15(2015) No.14, p.72-77.

[8]. Wang Zhihui, How to promote brand loyalty based on the perspective of network brand community research. E-Business Journal. Vol. 15(2015) No.4, p.29-30.

[9]. Ravi Pappu Pascale G.Q uester, Brand innovation how to influence brand loyalty. European Journal of Marketing.Vol.50 No.1/2(2016), p.2-28.

[10]. Sherri Silver, Top 5 Tips for Building Brand Loyalty. Insurance Marketing. Vol. 15(2015) No.6, p.12-13.

[11]. Janine Empen Jeter Loy Christoph Weiss, Price promotions and brand loyalty. European Journal of Marketing.Vol.49 No.5/6(2015), p.736-750. 